CIRR XXIII (78) 2017, 37-56

ISSN 1848-5782

UDC 339.92:327/474.3:5101

DOI 10.1515/cirr-2017-0006

\title{
Towards a Balanced Synergy of Visions and Interests: Latvia's Perspectives in $16+1$ and Belt and Road Initiatives
}

Andris Spruds

\section{Abstract}

The article analyses China's $16+1$ and Belt and Road initiatives from Latvia's perspective. Although the initiatives provide engagement on a large scale, it is challenging to achieve the task of achieving a synergy between a variety of stakeholders and interests in the context of a diversity of visions and agendas. The strategic dimension of transcontinental initiatives complicates further the building of synergy. Connectivity is an important and promising principle of both initiatives and transcontinental infrastructural linkages are especially high on the agenda. Mutually beneficial progress, however, must yet be achieved. In times of uncertainty, Central and Eastern European countries, including Latvia, are engaged in a balancing process of potential economic benefits and strategic implications of the $16+1$ and Belt and Road initiatives.

\section{KEY WORDS:}

China's Belt and Road Initiative, China-CEEC, connectivity, Latvia 
The Summit of China and Central and Eastern European countries in Riga in November 2016 became a formative and symbolic experience for Latvia, in the context of its relationship with China. Hosting the summit was perceived and framed in Latvia as extending and deepening the country's engagement and mutual trust-building with China. The gathering of representatives from China and Central and Eastern European countries was also considered as an opportunity to take economic and diplomatic advantage of the 16+1 partnerships and China's ambitious Belt and Road Initiative (Kučinskis 2016). At the same time, the summit in Riga provided an appropriate moment to reflect and assess the developments and prospects of both $16+1$ and the Belt and Road Initiative.

The article will analyse China's two initiatives towards Central and Eastern Europe and beyond, from Latvia's perspective. In order to achieve this goal several research questions must be addressed: Who are the stakeholders and what are their interests in an intensifying interaction between China and Central and Eastern European countries in general, and Latvia in particular? How is connectivity, as one of the major declared objectives of the two initiatives, being deliberated and implemented? What is the strategic context for the $16+1$ and Belt and Road Initiatives?

The paper is structured corresponding to the above questions. The first part of the paper focuses on the challenging task of charting the diversity of visions, agendas and interests involved in the two initiatives. It outlines both the opportunities and constraints to the synergy between a variety of stakeholders and interests. The second section elaborates on the important principle of connectivity. Although connectivity may embrace a number of aspects, the main attention here is on the developing economic and infrastructural linkages, as they can readily demonstrate concrete practical steps and achievements. The last part of the paper analyses the strategic dimension of transcontinental initiatives. In times of uncertainty, Central and Eastern European countries, including Latvia, must increasingly take into account both the economic benefits and strategic implications of the $16+1$ and Belt and Road Initiatives.

The paper is based on a growing number of scientific and analytical resources. Scientific literature on China's international ambitions and activities is abundant (Lanteigne 2016; Carver 2016; Tan Li, Larry D. Qui 
and Ying Xue 2016). With the advent of the New Silk Road idea, scientific research focused specifically on China's "going out" strategy is rapidly increasing (Godement and Kratz 2015; Hongying Wang 2016; Wang Yiwei 2016; Ghiasy and Jiayi Zhou 2017). However, the analysis of the role, place, and perspectives of the Central and Eastern European countries vis-à-vis China's ambitious initiatives is more fragmentary. The distribution and scope of research findings on Central and East European countries relations with China remains rather limited and unevenly spread among the countries and institutions in the region. At the same time, "islands" of regional expertise on relations with China in Central and Eastern Europe are forming. These islands look beyond bilateral interaction and place the $16+1$ format into a wider context. Among the CEE countries, Poland has demonstrated increasing capacity and resources in assessment of China's strategy and activities, including in the Central and Eastern European region (Jakoby 2016; Kaczmarski 2016; Jakobowski 2015; Szczudlik 2016). Moreover, opportunities and constraints for synergies with China's various initiatives have also been discussed by Chinese counterparts (Liu Zuokui 2016a; 2016b). The research in the Baltic countries essentially reflects thoroughly on China's motivations and the implications for the Baltic states and the wider region (Andrijauskas 2015). Analysis in, and on, Latvia in the context of China's initiatives fits into this regional picture and necessitates further research. Most research activity in Latvia on China's global and regional initiatives has been carried out under the auspices of the Latvian Institute of International Affairs (Andžāns and Sprūds 2016).

\section{Managing diversity: visions, agendas and interests}

A strategic vision is indispensable for a transcontinental, inter-civilizational, and infrastructural endeavour on the scale envisaged by China's Belt and Road Initiative. China's opening towards the West is based on the win-win philosophy of mutual understanding, respect and benefit (Li Keqiang 2016). The initiative aims to contribute to the creation of an embracing, inclusive, and pluralistic community. The Belt and Road Initiative has facilitated a mental re-mapping of geographic space and has already gained the image of a grand engagement, inter-civilizational connectivity and 
mutual enrichment. Latvia has not been an exception here, experiencing an emergence of China on the country's mental maps and political and business agenda in recent years (Martyn-Hemphill and Morisseav 2015).

A grand design or grand dream clearly helps to establish a normative basis to drive forward the concrete initiatives and projects. Cooperation in the 16+1 format may be perceived as an integral part of the wider and more ambitious Belt and Road Initiative (Liu Zuokui 2016a). China's Belt and Road Initiative involves allegedly 65 countries, and 16 of them are in Central and Eastern Europe. Central and Eastern Europeans see this as their opportunity to jointly appear on China's political and business agenda. However, the complexity and challenge to harmonising the variety of visions, agendas and interests at play has apparently been unachievable in the process. Latvia has experienced a multifaceted trajectory in its opening to the East in general, and China in particular, during the last decade.

Latvia's active engagement with Asian countries essentially began with the country's active participation in the Northern Distribution Network. The Northern Distribution Network became an important catalyst for opening to the East. In 2009 Latvia started to play a significant role in this network of transportation lines, launched and developed above all by the United States, to supply both its own and allied troops in Afghanistan (Rikveilis 2012: 86). Latvia grew into one of the most central and dynamic supply routes to Afghanistan via Russia and Central Asian countries. Although Latvia's visible role in the Network lasted a rather limited period of time from 2009 until 2013, it had considerable conceptual and political implications. The participation in this transcontinental supply endeavour motivated Latvia's decision-making and business community to think and act beyond the geographic and designed limits of the project. Commercialization of the existing network and extension of its connections to the immense economies of China and India increasingly entered Latvia's diplomatic and business thinking and agenda (Andžāns 2013: 9-29).

The importance of and adherence to the Trans-Atlantic dimension initially found its presence in the concept of the New Silk Road promoted by the United States (Starr 2007: 5-32). However, the limitations of the US New Silk Road initiative emerged soon (Standish 2014). The uncertainty of the US 
initiative and the emerging prospective of economic opportunities in the context of China's own Silk Road thinking, motivated Latvia, alongside Estonia and Lithuania, to join the format of 16+1 established in 2012. Taking into account China's implicit objective to limit US presence in developing major mainland routes in Eurasia (Fallon 2015: 140-147), the evolution and pragmatic turn of Latvia's and its partners' positions become noticeable.

European necessities have provided another dimension to the somewhat challenging task of reconciling a variety of visions and agendas and promoting synergy in the context of the 16+1 format. 11 Central and East European countries of the format have become members of the European Union. This has added to the importance of the region in the eyes of the Chinese, whose regional presence may become a window of opportunity for them to shape relations with the EU. On the other hand, Central and East Europe has been perceived as an "outskirt" of the European Union, which is obliged to follow the Community's requirements and instructions (Kaczmarski and Jakobowski 2015). Hence, the region has arguably become a certain backdoor into the EU and Europe at large for China's political and business interests.

Central and East European countries have had their own challenge with their membership in the $16+1$ format. This is the first and only regional, institutionalized formation within the EU engaging with China. Although a number of larger member states have developed intensive bilateral relationships, other EU members and the European Commission have perceived $16+1$ as a fragmentation of common diplomatic standing and trade and investment policies. This has been complicated by the fact that the 16+1 format also includes non-members of the Union. Latvia has grasped the sensitivity of the situation. In the context of Russia's aggression in Ukraine, a common stance on foreign policy has been deemed of paramount importance for the country on the "frontline". The summit in Riga emphasized synergy among the $16+1$, the Belt and Road initiative and, indicatively, an EU-China common platform (Riga Guidelines 2016). This has been a skilful endeavour to engage all three.

The Riga Summit pinpointed diversity within the $16+1$ format. The Central and East European countries vary in terms of size and capacity, perceptions and interests, relations and affiliations. Most of the countries are members 
of the EU and NATO. Five states have decided to integrate into the core of EU integration: monetary union. Poland is the only country from the region to become a founding member of the Chinese led Asian Infrastructure Investment Bank. If one paraphrases Henry Kissinger and asks what is the phone number for Central and East Europe, there would not be a single response. Moreover, the stakeholders - governments, businesses, nongovernmental institutions - occasionally compete among themselves for access, attention and resources. Management of diversity becomes both a challenge and reflection of an ever-growing web of linkages, mutual interests and increasing connectivity.

\section{Economic and Infrastructural Connectivity}

Connectivity has become the defining feature of China's modern Silk Road initiatives. Inter-civilizational and people-to-people engagement is important. At the same time, economic connectivity has also become one of the primary goals of both the 16+1 format and Belt and Road Initiative. The Medium Term Agenda for Cooperation between China and Central and Eastern European Countries, or Suzhou Guidelines, have underlined the intention that "China and CEECs will further facilitate mutual investment and trade and aim to make trade and investment relations one of the most dynamic growth points in 16+1 cooperation" (Medium Term Agenda 2015). Trade and investment has already increased considerably. China's 65 USD billion trade with its Central and East European partners in 2015 exceeded for the first time the trade with neighbouring Russia, which has been a traditionally close trading partner. However, it must be added that considerable and increasing trade deficits create some concerns and reservations on the part of the Central and Eastern European countries (Jitaru and Pralea 2016).

The Baltic countries, including Latvia, follow the general regional patterns of intensifying trade and investment interaction. Since the inauguration of the 16+1 format in 2012, Latvia-China trade has increased considerably (Andžāns and Bērzina-Čerenkova 2017: 163-172). The trade growth was further facilitated by the recovery of Latvia and its Baltic neighbours from 
a profound economic recession. Moreover, Latvian businesses began to look increasingly to the East to diversify its markets. Latvia has successfully gained a wider access to China's market, exemplified by Latvia's doubled export volumes to China in recent years. The agreement, which has provided access for Latvia's fish and dairy products to China's markets in 2015, has demonstrated the positive dynamic of upgraded cooperation. Although Latvia still faces a sizeable trade balance deficit with China, an interest to advance mutually beneficial trade relations between the two sides apparently remains strong (Kučinskis 2016).

Trade promotion and increasing mutual awareness has become an integral part of strengthening economic connectivity. The Belgrade Guidelines of 2014 encouraged and introduced a number of initiatives to promote mutual trade links (Belgrade Guidelines 2014). As one of the most visible results, China's International Consumer Goods Fair in Ningbo has become a platform to advertise the products from the region in a specifically tailored fair for Central and East European countries. Latvia has actively taken advantage of the opportunity to motivate its country's businesses and promote its goods in China. In this process, the major role has been played by Latvia's Investment and Development Agency. This agency, responsible for coordinating and supporting foreign investment and trade cooperation, has actively disseminated information, engaged with entrepreneurs, set up a fair pavilion and, indicatively, established a representative office in Ningbo. These activities can be perceived as foundational to more intensified cooperation in the future (Latvian Ministry of Economics 2016).

Mutual investment is slowly following a positive trend. The Baltic countries have also been willing to advertise their performance in developing and possessing intellectual capital, providing a professional workforce for businesses with a potential to establish regional R\&D or technologically advanced business centres. However, attracting considerable investment from China to the Baltic countries has proven to be a challenging endeavour. The knowledge and experience of the region on the Chinese side appears to be rather limited. Moreover, the Baltic counterparts are just starting to gain knowledge of how to build trust and make concrete steps towards cooperation with their Chinese partners. The relatively small sizes of the countries, in a geopolitically challenging environment, 
apparently dampened enthusiasm for immediate cooperation and direct linkages. Hence, the political, societal, institutional and increasingly business investment has yet to yield its economic fruits.

The infrastructural connectivity of the East and West has become centrepiece of mutual interest and engagement. The development of the 'hardware' of transportation infrastructures and 'software' of a formal and informal regulatory framework has been at the heart of the modern Silk Road vision. Connectivity contributes to the synergy between the Belt and Road Initiative and 16+1 formats. The Suzhou Guidelines of 2015 clearly prioritized the importance of the Eurasian transport corridor for China and its Central and East European partners:

"The Participants will work to reinforce a safe and efficient connectivity network on land, at sea and in the air between China and Europe, in conjunction with key transport passages, linkages and projects, and jointly build the New Eurasian Land Bridge Economic Corridor. This way, the Participants hope to make fresh contribution to Eurasian connectivity." (Medium Term Agenda 2015)

Central and East European countries have already been actively placing nationally advanced infrastructural projects on a common agenda. The region's governments and businesses see the potential for Central and East Europe being a hub, bridge, and gateway between the East and West. Regional projects contribute to both complementarity and competition.

Latvia, Estonia and Lithuania have traditionally emphasized the region's comparative advantages such as favourable location and considerable experience in transit and logistics. Their welldeveloped port and railroad infrastructure has provided a basis for international business partnerships with the three Baltic countries. The transport sector has been a major source of revenue to the Baltic economies. The modern Silk Road idea and engagement with China has grasped the imagination of decision-makers and the business community of the Baltic nations. The Belt and Road Initiative has contributed to thinking about transcontinental 
Eurasian transportation corridors. The $16+1$ platform has provided a concrete platform to turn ideas into some concrete projects. But the location of the Baltic States and relatively small size also entail some limitations, so concrete results are yet to be seen.

Latvia arguably has been most active among the Baltic nations in transport diplomacy. Latvia succeeded in becoming a coordinating country for logistics in the 16+1 format. It was decided at the Suzhou Summit in 2015 that Latvia would set up the CEEC-China Secretariat on Logistic Cooperation under the Ministry of Transport (CEECChina Secretariat 2017). The first 16+1 Transport Ministers' meeting was held in Riga in May 2016. The country's officials reiterated support for the New Silk Road initiative and the 16+1 format as "a significant platform for practical cooperation, attraction of new cargos and implementation of joint investment products in transport and logistics" (Ozolinšs 2016). Latvia has expressed its ambitions of being integrated into the Belt and Road transit and distribution networks and its expectations of attracting Chinese investment in infrastructure and transportation. A green-field or port infrastructure investment, or regional customer and executive centre for a major Chinese company, or increase of transportation flows through the region, would be deemed as a success.

The overall support for intensifying infrastructural connectivity has hidden a diversity of approaches and interests. Implicit dilemmas exist on how to find the right balance and synergy between wider regional, national and intra-national interests and approaches. Chinese counterparts have emphasized inter-regional cooperation in promoting a mutual interconnectedness. The Baltic Sea ports have apparently been perceived in China's approach in the wider context of Black Sea, Adriatic Sea and Baltic Sea connectivity. Indicatively, during the Transport Ministers' meeting China's representatives underlined the importance of the synergy between regional connectivity aspiration under the 16+1 framework, and EU regional policies such as the EU Strategy for the Baltic Sea Region (Bērzina-Čerenkova and Sprūds 2017). Although the Three Seas connectivity idea could contribute to the development of a SouthNorth Corridor in the CEE region, its economic value for the Baltic countries and its regional counterparts is not clear. 
The intra-regional and intra-national dynamics and competition further add to, and occasionally complicate, the complex connectivity agenda (Baltic News Service 2017). The Chinese side has indicated its interest in cooperation with the Baltic countries in the context of China-led development of the Great Stone Industrial park in Belarus. Given that Belarus is a landlocked country, a considerable potential exists to integrate the Baltic ports in a chain of supply and distribution (Korol 2016). Klaipeda port in Lithuania has apparently made the most tangible progress to become a regional partner, by integrating its facilities into the developing distribution network through existing and expanded railway infrastructure. Although the authorities of the largest Latvian ports of Riga and Ventspils have been promoting the idea of developing a logistics base in Latvia, in close cooperation with Chinese counterparts, international and intra-national competition has actually made it challenging to speak with a single voice even on a national level.

The potential for China's cooperation with Latvia, Estonia and Lithuania in infrastructural connectivity could proceed in multiple directions. Chinese businesses have demonstrated their interest in large-scale infrastructure projects in Central and East Europe, including the Baltic region. Rail Baltica, which plans to connect the three Baltic countries with a fast-speed European size railway system, has been an attractive large-scale infrastructural project. This EU supported project provides both investment opportunity and potentially profitable business prospects for the infrastructure developing and construction companies. At the same time, the EU legislative and regulatory framework creates strict and transparent tender conditions in a highly competitive business environment. Participation of China's companies in the construction of this project has been discussed without the agreements being finalized (Baltic Course 2016). Similarly, the ideas of cooperation in the air transportation sector, and direct air connection between Latvia and China, have been deliberated but are yet to be developed. Hence, Latvia's regional connectivity hub ambitions in the context of the Belt and Road Initiative and the 16+1 format continue to be in the making. 


\section{Beyond connectivity and CEE: strategic dimension of transcontinental visions}

The Belt and Road Initiative is an ambitious vision that has encouraged enthusiasm and interest among many stakeholders. Countries in Central and East Europe unsurprisingly have rushed to the regional format of $16+1$ to speed up economic engagement with China, connectivity and infrastructural development and societal interaction. The modern Silk Road is still evolving a long-term vision with both economic and strategic implications. Although the economic rationale has dominated the $16+1$ agenda, the countries in the region may increasingly deliberate on the strategic and security dimension of China's transcontinental vision of Eurasia. For Latvia, alongside its Baltic neighbours of Estonia and Lithuania, strategic assessment of their participation in a Chinese led agenda becomes an integral part of its strategic calculation.

China's opening Westward's has an assortment of motivations. It may still be unclear what the geopolitical underpinnings of China's vision are. However, China's proactive stance, strategic concepts and growing economic presence are facilitating its increasing role in global governance and regional security affairs. China is steadily becoming a formative global security actor with its own interests and interpretations. China shapes globalization through its various connectivity initiatives. The New Silk Road concept combines China's centred vision and unilateral approach with Western principles of regionalism and multilateralism (Kaczmarski 2016). This raises questions about whether China's geopolitical agenda is actually converging or diverging with fundamental security paradigms and the interests of Central and Eastern European countries, including Latvia, Estonia and Lithuania. The picture is clearly mixed.

The convergence of interests between China and CEE countries takes place in Central Asia. Central Asia is vital in the context of developing critical infrastructure links for sustainable transcontinental transport corridors, and the vision of connectivity between the Eastern and Western parts of Eurasia. Stability in the heart of Asia is essentially a precondition for a successful Belt and Road Initiative and 16+1 cooperation. China 
has become an indispensable actor in the diverse Central Asian region. China's overall increasing political and economic presence and its Belt and Road Initiative may have positive implications for the region. Central Asian countries gain more room to manoeuvre to balance their dependence on Russia, receive an additional boost for economic growth and socio-economic stability, and could be motivated to cooperate more regionally. On the other hand, the Belt and Road Initiative's resources may further deepen endemic corruption and regimes' proclivity to tighten control in the context of growing interdependence (Ghiasy and Jiayi Zhou 2017: 19-28).

Latvia has had a proactive approach in Central Asia. Although one must not overestimate Latvia's political and economic footprint in Central Asia, the country has played an active role in the region alongside such players as Germany in recent years. During its presidency of the EU Council in 2015, Latvia built on previously established common experiences and cooperation. The presidency served as a platform to promote the country's links and interests in Central Asia. Latvia supported a comprehensive review of the EU Strategy on Central Asia, and renewal of the position of the EU's Special Representative for Central Asia (Pastore 2017: 151-162). Estonia intends to continue the trend during its EU presidency in the second part of 2017. Cooperation in border security, education and connectivity have been the top priorities on Latvia's agenda. Latvia's transport diplomacy and its endeavours to play a more important role in Eurasian transport corridors essentially started in the Central Asian countries of Kazakhstan and Uzbekistan, in the context of the Northern Distribution Network. The dilemmas created by a divergence of values and interests amongst the parties were largely solved in favour of practical and pragmatic cooperation. Apparently an interest-dominated approach may facilitate cooperation among a variety of stakeholders in Central Asia under the Belt and Road Initiative.

The implications of the Belt and Road Initiative for Russia and its role are more difficult to assess. Likewise, Russia's strategic moves may have mixed consequences for the Initiative and its connectivity dimension. Russia's sovereign multipolar thinking makes it a complicated partner in transcontinental win-win endeavours. Russia's assertiveness in the postSoviet space, which it apparently is willing to approach as its backyard, 
preclude from building a wider community of mutual trust and respect. Quite the opposite, Russia's aggressiveness in Ukraine invoked ghosts of insecurity and neo-imperialism and was a regional security wake-up call for many neighbouring countries. Moreover, Russia promotes and develops its own integration project of the Eurasian Economic Union, including in Central Asia, and has approached jealously any potentially competitive visions (Makocki and Popescu 2016: 47-49). The time of overlapping integrative spaces in Russian strategic thinking has evidently passed.

On the other hand, the picture is more complex when accounting for China's relationship with Russia. China has become a vital and strategic partner for Russia in the so-called anti-hegemonic and multipolar world approach. Russia and China have been able, so far, to arrive at some division of labour in Central Asia. While Russia has been largely shaping military and political developments, China has ensured its predominant economic presence. Moreover, Russia and China have strategically promoted closer economic cooperation between themselves, especially in the energy sector. Development of transport corridors through Russia in the context of the Belt and Road Initiative may provide Russia with both economic gains and political leverages in the wider Eurasian area (Kaczmarski and Rodkiewicz 2016).

Russian assertiveness has undoubtedly alarmed Central and Eastern European countries. Western sanctions and deterrence measures against Russia have demonstrated even wider consensus and understanding in the Euro-Atlantic Community of Russia's dangerous strategic behaviour. Russia and China's forging of an alliance to promote a post-Western world adds to the strategic dilemmas for NATO and the EU, especially their Central and Eastern European members. At the same time, economics matter. Sanctions fatigue is noticeable. Russia's enormous territorial landmass makes it indispensable for implementing the connectivity vision of the Belt and Road Initiative. Central and Eastern Europeans have most to lose from Russia's aggressive undertakings, but they also have the most to gain from constructive and pragmatic economic engagement with a large neighbour. Latvia faces this Central and East European dilemma even more acutely due to direct proximity to Russia. Russian military exercises remind Latvia regularly of its insecurity concerns, while cargo 
flows from Russia of mutual economic interest, perhaps even necessity from the Latvian perspective. Latvians are willing to cooperate with Russia and its EEU partners of Belarus and Kazakhstan economically, despite the existing sanction regime. Hence, the visions and agendas of the 16+1 and Belt and Road Initiatives, and especially its connectivity priority in Central and East Europe in general and Baltics in particular, are caught in the crossfire of ambitions, compromises and geopolitical developments.

EU-China engagement adds to the complexity of the situation. The EU's new Global Strategy declares that the EU will "pursue a coherent approach to China's connectivity drives westwards" (European Union 2016). However, the "coherent approach" is apparently in making. The signing of a Memorandum of Understanding on an EUChina Connectivity Platform to "enhance synergies" between the Belt and Road Initiative and EU's Investment Plan for Europe might not be enough. Europe is clearly placed in China's transcontinental strategic vision. The Belt and Road and 16+1 initiatives are motivating the EU to think more strategically. The EU-China Connectivity Platform will not become a substitute for strategic vision and will not create a community of the like-minded in Eurasia. The EU may need to put more emphasis on promoting a rules based global order for global and regional governance. Although clearly the "rules based order" could be interpreted through the prism of national interests, a number of agendas converge. The EU and China are both interested in dealing with current traditional and non-traditional global and regional security challenges such as terrorism, cyber security, energy and environment, human development and resilience. This creates a platform for more coherent engagement (Ghiasy and Zhou 2017: 45-56).

The $16+1$ format comes into the strategic picture of EU-China relations as both a nuisance for Brussels and dynamic test ground for a further engagement. The 16+1 initiative has been perceived by some in the EU as China's deliberate creation of its regional "Trojan horse" in the EU policy-making corridors (Stanzel et al. 2016). On the other hand, in the absence of common voice, the 16+1 platform has become a test ground for also developing the EU's strategic thinking and practical cooperation in connectivity, trade and investments (Long Jing 2016: 25-28). 


\section{Conclusions}

China'stranscontinental connectivityinitiativeshave obtained momentum. This is a success in times of uncertainty. The Belt and Road Initiative remains a non-institutionalized cooperation work-in-progress and will be shaped by a variety of stakeholders. The 16+1 format has developed into a dynamic institutionalized platform with a spectrum of challenges and opportunities. Positive spill-over from this vision of engagement, intensifying economic cooperation and regional stability will depend on mutual interest and the ability to harmonize competing interests and find synergy. A number of synergies must be achieved in the Eurasian space to achieve political, human, economic and infrastructural connectivity. The European Union, Eurasian Economic Union, Eastern Partnership and Shanghai Cooperation Organization are only a few institutional frameworks and initiatives that must be taken into account.

Latvia, Estonia and Lithuania, alongside other CEE countries, have been pro-active to facilitate cooperative efforts and extend the mutually beneficial political, economic and people-to-people engagement with China. The Fifth Summit of the Prime Ministers of China and Central and Eastern European countries in Latvia's capital Riga, in November 2016, was indicative of the interest in and understanding of the importance of cooperation with China. The Baltic States have been closely engaged in Baltic Sea region interaction and have fully integrated into the European Union. Latvia deems the $16+1$ format as an important complementary platform to the wider EU-China dialogue, and has supported the vision of the Belt and Road. The prospects of cooperation between China and its Central and Eastern European counterparts have been and will be shaped by an assortment of challenges and opportunities. The synergy of the two initiatives becomes both a significant measurement and prerequisite for further development of mutually beneficial partnerships. Latvia, alongside other Baltic countries, faces its own choices of striking the right balance in a productive engagement with China in the context of its flagship initiatives. Thus, for Central and East European countries, especially small countries like Latvia, these Chinese initiatives create both challenges and opportunities. Yet, playing proactively at several diplomatic and business chessboards has become a matter of necessity rather than choice. 


\section{B Bibliography}

Andrijauskas, K., 2015. China's Economic Penetration into Post-Soviet Central Asia and Eastern Europe. Lithuanian Foreign Policy Review, September: 113-131.

Andžāns, M., 2013. The Northern Distribution Network and Its Implications for Latvia. In: Spruds, A. and Potjomkina, D., eds. Nothern Distribution Network: Redefining Partnerships within NATO and Beyond. Riga: Latvian Institute of International Affairs: 9-29.

Andžāns, M. and Sprūds, A., eds., 2016. Afterthoughts: Riga 2016 International Forum of China and Central and Eastern European Countries. Riga: Latvian Institute of International Affairs.

Andžāns, M. and Berzing-Čerenkova U. A., 2017. 16+1 and China in Latvian Foreign Policy: Between Values and Interests. In: Sprūds, A., Bruǵe, I. and Bukovskis, K., eds. Latvian Foreign and Security Policy Yearbook 2017. Riga: Latvian Institute of International Affairs: 163-172.

Baltic Course, 2016. China interested in investing in Rail Baltica and airBaltic. [online] 19 February. Available at: http://www.baltic-course.com/ eng/transport/?doc=116991.

Baltic News Service, 2017. Lithuanian Prime Minister Saulius Skvernelis: Lithuania should overcome Latvia in competion battle for Chinese investments. [online] 15 April. Available at: http://news.lv/The Baltic_Times/2017/04/20/pm-lithuania-should-overcome-latviacompetition-battle-chinese-investments/print.

Belgrade Guidelines for Cooperation between China and Central and Eastern European Countries, 2014. [online] 17 December. Available at: http://www.fmprc.gov.cn/mfa_eng/wjdt_665385/2649_665393/ t1224905.shtml.

Bērzinga-Čerenkova, U. A. and Sprūds, A., 2017. The Belt and Road Initiative in the Context of China-Central and Eastern European Cooperation: Latvia's Perspective. In: Jiemian, Y. and Obradovic, Z., eds. China and Central-Eastern Europe: New Cooperation at Old Silk Road. 
Shanghai: Foreign Language Education Press.

Carver, J. W., 2016. China's Quest: The History of the Foreign Relations of the People's Republic of China. Oxford: Oxford University Press.

CEEC-China Secretariat on Logistic Cooperation Information Platform, 2017. China and CEEC cooperation: Latvia. [online]. Available at: http://www.ceec-china-logistics.org/en/about-us/info/.

European Union, 2016. A Global Strategy for the European Union's Foreign and Security Policy. Shared Vision, Common Action: a Stronger Europe. [online] June. Available at: http://eeas.europa.eu/ archives/docs/top_stories/pdf/eugs_review_web.pdf.

Fallon, T., 2015. The New Silk Road: Xi Jinping's Grand Strategy for Eurasia. American Foreign Policy Interests, 37(3): 140-147.

Ghiasy, R. and Jiayi Zhou, 2017. The Silk Road Econonomic Belt: Considering Security Implications and EU-China Cooperation Prospects. Stockholm: SIPRI.

Godement, F. and Kratz, A., 2015. "One Belt One Road": China's great leap outward. European Council on Foreign Relations China Analysis, [online] June. Available at: http://www.ecfr.eu/page/-/ China_analysis_belt_road.pdf.

Hongying Wang, 2016. A Deeper Look at China's "Going Out" Policy". CIGI Commentary, [online] March. Available at: https://www.cigionline. org/sites/default/files/hongying_wang_mar2016_web.pdf.

Jakoby, M., 2016. Chiny bez makijazu. Warsaw: Muza.

Jakobowski, J., 2015. China's foreign direct investment within 16+1 cooperation formula: strategy, institutions, results. Centre for Eastern Studies Commentary, [online] 27 November. Available at: https:// www.osw.waw.pl/en/publikacje/osw-commentary/2015-12-03/ chinas-foreign-direct-investments-within-161-cooperation.

Jitaru, L. and Pralea, S., 2016. EU-China Trade Partnership: Strategic Importance of Central and Eastern European Members. Ovidius University Economic Science Series, [online] 16(2): 37-41. Available at: http://stec.univ-ovidius.ro/html/anale/ENG/2016/2016-II-full/s1/8.pdf. 
Kaczmarski, M. and Jakobowski, J., 2015. China and Central-Eastern Europe: ' $16+1$ ' as seen from Beijing. Center for Eastern Studies Commentary, [online] 15 April 2015. Available at: https://www. osw.waw.pl/en/publikacje/osw-commentary/2015-04-14/chinacentral-eastern-europe-161-seen-beijing.

Kaczmarski, M. and Rodkiewicz, W., 2016. Russia's Greater Eurasia and China's New Silk Road: adaptation instead of competition. Centre for Eastern Studies Commentary, [online] 21 July. Available at: https://www.osw.waw.pl/sites/default/files/commentary_219.pdf.

Kaczmarski, M., 2016. 'Silk Globalisation': China's Vision of International Order. Centre for Eastern Studies Point of View, [online] October. Available at: https://www.osw.waw.pl/en/publikacje/pointview/2016-10-10/silk-globalisation-chinas-vision-international-order.

Korol, A., 2016. A. Korol: Belarus is to become an important link of the Silk Road Economic Belt. [online] July. Available at: http://lithuania. mfa.gov.by/en/embassy/news/c44af903e602aa19.html.

Kučinskis, M., 2016. Speech by Latvian PM at China-CEEC Business Forum during Riga 16+1 Summit. [online] 6 November. Available at: http://m.Ivportals.lv/visi/viedokli?id=283096? show=coment.

Lanteigne, M., 2016. Chinese Foreign Policy: An Introduction. London: Routledge.

Latvian Ministry of Economics, 2016. Cooperation with China. [online] 7 September. Available at: https://www.em.gov.Iv/lv/jaunumi/11271latvijas-uznemumi-ieintereseti-attistit-sadarbibu-ar-kinas-lielakoostas-pilsetu-ningbo.

Li Keqiang, 2016. Speech by China's PM at Riga Summit of China and Central and Eastern European Countries. [online] 5 November. Available at: http://www.scio.gov.cn/32618/Document/1515591/1515591.htm.

Liu Zuokui, 2016a. The Role of Central and Eastern Europe in the Building of Silk Road Economic Belt. China-CEEC Think Tanks Network Research Paper, [online] 11 January. Available at: http://16plus 1-thinktank. com/1/20160111/1096.html.

Liu Zuokui, 2016b. How the Chinese Perceive the Visegrad Group. China- 
CEEC Think Tanks Network Research Paper, [online] 2 October. Available at: http://16plus 1-thinktank.com/1/20161002/1207.html.

Long Jing, 2016. The Transition of EU's Attitude Towards '16+1. In Andžāns, M. and Sprūds, A., eds. Afterthoughts: Riga 2016 International Forum of China and Central and Eastern European Countries. Riga: Latvian Institute of International Affairs: 25-28.

Makocki, M. and Popescu, N., 2016. China and Russia: an Eastern partnership in the making? ISSUE Chaillot Paper, [online] No. 140, December. Available at: https://www.iss.europa.eu/content/ china-and-russia-eastern-partnership-making.

Martyn-Hemphill, R. and Morisseau, E., 2015. Small Step for China- Giant Leap for the Baltics? The Baltic Times, 5 February.

Medium-Term Agenda for Cooperation between China and Central and Eastern European Countries, 2015. [online] 24 November. Available at: $\quad$ http://www.fmprc.gov.cn/mfa_eng/zxXX_662805/†1318038. shtml.

Ozolinšs, K., 2016. China praises Latvia's contribution in coordinating 16+1 transport ministers meeting. LETA News Agency. 15 January.

Pastore, G., 2017. Latvia and Central Asia: From Visibility to Practical Work. In: Sprūds, A., Bruǵe, I. and Bukovskis, K., eds. Latvian Foreign and Security Policy Yearbook 2017. Riga: Latvian Institute of International Affairs: 151-162.

Riga Guidelines for Cooperation between China and Central and Eastern European Countries, 2016. [online] 5 November. Available at: http://www.mfa.gov.Iv/en/component/content/article/55299-theriga-guidelines-for-cooperation-between-china-and-central-andeastern-european-countries? Itemid=353.

Rikveilis, A., 2012. Twenty Years of Latvian-American Defence Cooperation: From a Cautious Beginning to a Strategic Partnership and Beyond. In: Indans, I., ed. Latvia and the United States: A New Chapter in the Partnership. Riga: Centre for East European Policy Studies: 80-90.

Standish, R., 2014. The United States' Silk Road to Nowhere. Foreign Policy, 29 September 2014. 
Stanzel, A., Kratz, A., Szczudlik, J. and Pavlićević, D., 2016. China's Investment in Influence: the Future of $16+1$ Cooperation. European Council on Foreign Relations China Analysis, [online] December. Available at: http://www.ecfr.eu/publications/summary/chinas investment_in_influence_the_future_of_161_cooperation7204.

Starr, F., ed., 2007. The New Silk Roads: Transport and Trade in Greater Central Asia. Washington DC: Johns Hopkins University.

Szczudlik, J., 2016. Perspektywy formatu Chiny-Europa SrodkowoWschodnia (16+1). PISM Biuletyn, [online] 18 November. Available at: http://www.pism.pl/files/?id_plik=22613.

Tan Li, Larry D. Qui and Ying Xue, 2016. Understanding China's Foreign Trade Policy: A Literature Review. Frontiers of Economics in China, $11(3)$ : 410-438.

Wang Yiwei, 2016. The Belt and Road: What Will China Offer the World in Its Rise. Beijing: New World Press.

Andris Spruds (andris.spruds@liia.Iv) is the Director of the Latvian Institute of International Affairs. He also holds the position of Professor at Riga Stradins University. He has an MA in Central European History from CEU in Budapest, Hungary, and in International Relations from the University of Latvia. He has also obtained a PhD in Political Science from Jagiellonian University in Krakow, Poland. He has been a visiting student and scholar at Oxford, Uppsala, Columbia and Johns Hopkins University, as well as the Norwegian Institute of International Affairs and Japan's Institute of Energy Economics. His research interests focus on the domestic and foreign policy of post-Soviet countries, China and Central Asia, transatlantic relations, energy and transport policies. 